\title{
Facadism: An Approach for Spatial Reconfiguration
}

\author{
Wahda Shuker Al-Hinkawi*, Nada Abdulmueen Hasan, Shireen Kamel Zedan \\ Architectural Engineering Department, University of Technology, Baghdad 10063, Iraq
}

Corresponding Author Email: wahda.s.mahmoud@uotechnology.edu.iq

https://doi.org/10.18280/ijdne.160603

Received: 20 October 2021

Accepted: 3 December 2021

Keywords:

facadism, urban contexts, spatial reconfiguration, historical axes and spaces

\begin{abstract}
Baghdad's historical center is a rich site of heritage and cultural values, yet it suffers from urban deterioration. Many urban spaces and historical structures are aging, which has caused a decline in the vitality and function of axes and open spaces. This research is based on the principle of facadism as one of the main approaches to the preservation and rehabilitation of historic and traditional buildings. The purpose is to address urban degradation and the spatial reconfiguration of urban space in a way that promotes its sustainability and revitalization. This research aims to formulate a theoretical framework that includes a list of interference patterns and their role in spatial reconfiguration. This will be applied to the spatial reconfiguration and development of Al-Rasheed Street in the historic center of Baghdad. A questionnaire elicited the opinions of experts, designers, and implementers in academic and executive institutions on the possibility of reshaping local spaces using facadism. The results of the questionnaire showed that experts support the possibility of adopting this method in spatial reconfiguration in order to intervene in the degradation of historical environments, and also to create a homogeneous and interconnected urban environment that prevents the eradication of cultural and urban heritage. By adopting the preservation of a façade in its various forms, considerations need to be made regarding its compatibility with the nature of the problems in the study area and the ineffectiveness of the pattern of dismantling and transferring a building to another place. This is due to the importance of the historical place and the need to preserve all its historical items within the fabric, in addition to the effectiveness of some detailed patterns in different items of formation.
\end{abstract}

\section{INTRODUCTION}

A large area of Baghdad's historical center and its buildings suffer from urban deterioration and physical and legal obsolescence, in addition to the damage of war and the displacement of people. This degradation is compounded by deliberate vandalism, which has resulted in many neglected or destroyed historical buildings. The lack of preservation policies, laws, and local legislations to deal with such cases has only made the matter worse [1,2]. This paper presents facadism as an approach to treat historical, obsolete, or degraded buildings within historical contexts for spatial reconfiguration, in order to protect these buildings and their urban spaces, to build space from humanistic history, by looking at deeply rooted human factors that give birth to distinct formal and artistic expressions and a particular style of the built environment, it should be possible to reveal some non-formal patterns that are, to some extent, resistant to time and thus contain the seeds on which continuity can grow. cultural ones - even in times of turmoil by powerful external forces [2].

The trend towards modern facadism arose in Europe and the United States to address the destruction of the built environment during World War II, as well as respond to development pressures in areas protected by heritage legislation, and facilitate tourism development. The early spread of these project patterns appears in Germany, France, Belgium, and the United Kingdom [3]. The first waves of facadism in Europe were analyzed in the seventeenth and eighteenth centuries, within the expression of Renaissance in Europe where the method was used to beautify city [4]. In particular, façades were used to preserve the few historical materials that remained during the reconstruction and development efforts in the city center that resulted in the demolition of swaths of the existing built environment, in response to development pressures later in the twentieth century $[3,5]$. Facadism was adopted in Washington, D.C. in the 1970s, with developers and preservationists using this approach in New York shortly after the 1980s [6, 7]. Since then, its application spread to Australia and other countries [8].

The traditional cities around the Mediterranean and beyond show individual uniqueness in their built form, general physical qualities, and features. Residents developed a strong sense of connection to their city and always remember with interest a sense of place in and around their neighborhood [9]. The growth of cities depended on man's existential experience and his ability to practice his common societal beliefs and values, which generated multiple parallel and differentiated cultural identities, which has grown over centuries of continuous interaction between man and his evolving natural and cultural environment [2].

For Baghdad the elements of the urban formation remained almost constant for long time, which were limited to the presence of the wall, and the compact fabric, with the presence of public buildings, the majority of which are religious, some built from the past and some during the modern time, of course, 
the river comes as an important element in the city, as well as the floating bridge that connects the two sides of the city [10].

The practice of facadism in Iraq is limited, and so this research aims to formulate a list of the method's types and its role in spatial reconfiguration. We used a questionnaire to elicit the opinions of experts about the possibility of using facadism to spatially reshape local buildings and to determine their preferences history.

Several steps have been adopted to achieve the research objective. The first step aims to define facadism and determine its most important types, as well as its role in spatial reconfiguration. We build a theoretical framework in the second step, and then establish a case study in the third step, which included reviewing the problems of the study area - AlRasheed Street in the historical center of Baghdad - and questioning the opinions of experts and specialists on the types of interfaces that can be applied locally, as well as their potential to activate the urban environment.

\section{DEFINING FACADISM}

A general definition of facadism is the preservation of an existing historical façade and its incorporation into a new build element [11]. As such, the façade of a historic building is the only part of a building preserved during the conversion process, while the remainder of the structure is severely altered or completely destroyed $[4,8,12]$.

Facadism can be defined also by a set of terms or concepts that have been given to this practice and its multiple interpretations within the directions of preserving historical buildings. Facadism is recognized as a growing urban trend, and a logical way to preserve the historic character of a street if an entire historic building is beyond repair. The method could also be explained as a way to modernize structures in historic urban centers to ensure modern accessibility, as well as fire and environmental standards, which provide a safer and more comfortable indoor environment for a more diverse group of users [13].

Facadism is a holistic approach to remodeling a city's townscape, where historical elements are preserved, duplicated, or copied, or when they evoke a typical style within contemporary townscapes to attain and enhance historical values, embellish certain qualities, or act as symbols and landmarks as reminders of great architectural traditions The method is the reproduction and re-creation of historical interfaces or their elements [5, 14].

Finkelstein addressed the distinction of the Federal Heritage Buildings Review Office (FHBRO) for facadism as a common compromise between demolition and new development. However, Finkelstein distinguishes it as an approach that undermines the integrity of the original building and its heritage character in favor of a contemporary design, or to meet the current height requirements from one to two stories, or more, in the event of a new building [14-17].

Facadism can also be used to refer to the rebuilding of a historical façade with new materials, perhaps in a changed form that meets the current height requirements of one to two floors (or more) in the event of a new building, or the creation of a façade in a certain style (usually historical) commensurate with the style prevailing in its surroundings, but carrying little or no relation to the spaces behind it $[15,18]$. However, such façades are radically altered. Facadism is a compromise between preservation and development of buildings, especially in historic centers when the preservation of historic buildings contradicts the plans of urban developers [19].

Some theorists hold opposing stances on facadism, from the point of modern architecture ideologies. For example, Nan Ellin (1999) criticizes postmodern architecture for its reliance on facadism and the tendency to present analyses based only on formal aspects of construction, regardless of material, history, or even function [20]. Loyer and Schmuckle-Mollard [4] considered it a practice consisting of reducing the historical value of the building to its façade, while its reconfigured interior design does not carry any memories of the past or its original function [4]. Rohiman [17] has shown that facadism occurs most of the time during adaptive reuse. Sometimes, buildings undergo drastic transformations, and as a result the mediation between the new and the current is often viewed to be out of proportion, with an architectural language and fully modified tectonic qualities. In such circumstances, the new structure creates disparities in tectonics and spatial design. The language of the new architecture does not emerge from the previous, as the latter sits uncomfortably as an attachment to the new, and thus its value is reduced [17].

According to Frecker [21], facadism is a faux heritage because it leaves only a thin mask of the original building, despite being classified as a method of preservation, so there is no relationship between the façade and its extension (in terms of style, proportion, and structure). Expansions unrelated to the façade are tense and often sharply contrast in terms of color and materials. Further, they are frequently not adequately adjusted, and thus any respect for the façade is lost. In some cases, it is a poor compromise to preserve the heritage, and the result is a meager façade covered in massive concrete and glass.

All these definitions and manifestations of facadism arise from different motives and produce different architectural results. However, they share a common characteristic, which acts as a generator of the controversy that seems to be rooted in facadism, whereby it leads to a separation of continuity between the inside and the outside [11].

From the preceding, the supportive and oppositional approaches to facadism in urban development become clear. The most prominent issue is the relationship between the façade and its expansion in style, proportion, and structure. Opponents criticize façade-unrelated extensions that are tense and often too contradictory in color and materials, and that are not adequately tuned.

\section{TYPES OF FACADISM}

The International Council on Monuments and Sites (ICOMOS) has proposed the following types of facadism:

\subsection{Preservation of the façade}

Highfield (2003) adopted the term 'façade retention,' not 'façade' [15, 22]. Wood, Kyriazi, and Robert, based on Highfield, have developed styles of preservation for the historical buildings, which include the following:

1-Scoop refers to the complete preservation of a building's façade to support and confirm the continuity and homogeneity of the urban scene. This is achieved by preserving one or more façades of the building with the creation of a new structure behind [23]:

Merge-replication, where merging and repetition take 
place. This process relates to the complete preservation of the historical façade and the re-establishment of the previous interior behind the historical façade and the integration of the two in one building.

Merge-contemporary interpretation: this relates to the collection (union) of a completely new structure that has an architecturally contemporary character with the historical façade, and connects and integrates physically in one building

2-Illusion refers to the retention of an exterior façade wall only. Between 10-20 feet or 20-40 feet are kept from the back of the façade to give the illusion (deception) of some depth besides the new construction. This is known as facadectomy $[3,12,15]$.

3-Collage/sheet refers to retaining a part or parts of a façade during demolition and incorporating elements into a new construction. It can also refer to the retention of the wall of the external façade and merges the façade into the new construction, resulting in the façade appearing as a wallpaper on the new building [12, 23].

4-Separation refers to preserving the historic façade and the modernization of the vacancy behind it with an entirely new development. The new fabric is distanced from the historical façade, and thus the old is physically separated from the new, creating a transition zone between the two [23].

\subsection{Faithful reconstruction}

1-In cases where the damage to the building is so great that the costs of preservation are prohibitively high, demolition and rebuilding the entire edifice is an option, providing that the new building is copied according to the original in terms of appearance and size [5].

2-Original façades that do not comply with modern standards are sometimes demolished, and then replaced by newly constructed facsimiles in front of modern buildings using new materials. In some cases, their original proportions are also changed [15].

\subsection{Dismantling and reconstruction}

Dismantling and reconstruction refer to the construction of a façade somewhere other than its original location $[3,12]$. Based on previous studies and their interpretations of various practices, this research defines facadism as an urban approach, mainly concerned with historic preservation of the built environment described through various technical practices. It is a comprehensive approach for spatial reconfiguration, with cultural, architectural, economic, and legislative motives through preserving the character of the historical urban scene, as well as promoting the historical values of symbols and landmarks as a means of restoring architectural traditions. Dismantling and reconstruction can meet the demands of contemporary societies to revitalize city centers, modernize their historical structures, and provide all amenities and conveniences to the place depending on its various patterns in terms of façade preservation, faithful reconstruction, and relocation.

\section{SPATIAL RECONFIGURATION}

The concept of spatial reconfiguration aims to create a homogeneous and interconnected urban environment, which prevents the extinction of cultural and urban heritage by adopting methods of facadism in order to intervene in and treat historical settings.

\subsection{Restoring urban memory}

Facadism is an approach that helps preserve a city's historical memory and gives its identity a characteristic uniqueness. The city remembers its past as a collective memory of its people. This can be achieved by:

-Preserving the urban character: facadism facilitates the preservation of the character of the historical street and its familiar scenes [24], and stimulates urban nodes. The preservation of features and the restoration of urban vitality could be achieved by ensuring compatibility between the old and the new and the enhancement of the originality of the urban fabric $[12,22]$, as well as recognizing the distinction between the old and the new in order to strengthen the urban origin and character of the city [24]. This does not mean that the new part and the historical buildings must be completely different in terms of design, materials, and other visual qualities, but rather that the new addition must take its designs from the historic building without direct reproduction of it [25].

-Investing in heritage values and symbols: the contextual value was referred to as one of the basic considerations of facadism and the role of those features and values in the city or street scene, such as the precedence of the general functional value within the context [18]. The role of current historical façades can affect the future of a city and the urban development process [24]. Urban restoration takes place through the preservation and restoration of old structures, as well as the introduction of new structures that differ in their implications and characteristics. The reconfiguration of mechanisms at the structural level includes the strengthening of the connected façades of the buildings, weaving their parts into a coherent design unit in which the old elements and the various parts are gathered, thus confirming the importance of continuity and preservation of the original form [26]. This strengthens societies by fostering deeper attachment to place and higher levels of social cohesion [27]

\subsection{Enhancing the character and identity of a place}

The importance of character and identity appear in keeping up with the historic fabric for the contemporary city while preserving its character and identity [28], and also valuing memory and collective consciousness. A place is a repository of residents' memories and historical events [24, 29].

The importance of facadism has been proposed as a culture policy as well as a form of heritage. Preserving historical cities includes various forms of social, historical, or cultural dimensions, and transferring cultural assets to future generations [23]. The most important principles of urban reconfiguration that enhance the personality and identity of the place in the new urban environment include:

-Preserving urban unity: preserving the continuity of the urban scene by returning to contextual patterns to show a strong sense of place [5]. This is based on the compatibility factors that were taken into account in the merging process between the old and the new (in terms of size, scale, color, proportions, materials) [30]. This is achieved through the following:

- Repeating similar elements in the urban scene. For example, a colonnade creates a rhyme and pattern that 
contributes to establishing the personality and identity of the urban scene [7]. Preservation of architectural unity within certain contexts can be so strong that they permit new development and justify the only sound option for facadism [18].

-Rhythm: achieving rhythm in façades requires stricter repetition than rhyme, which is derived from simple binaries to more complex repetitive subsystems to achieve amplification and avoid monotony. Therefore, both contradiction and diversification are essential in achieving rhythms that can be measured by achieving a sequential view of the urban scene [7].

-Balance: the role of facadism appears in organizing distinguished complex scenes that may appear chaotic. The major attraction of historic cities is the fusion and merging of scenes to reach an ideal balance and achieve the element of surprise [26, 31].

-Harmony: facadism achieves the distinction or difference between the old and the new, and establishes harmony with the historical personality of the urban scene [32].

\subsection{Reconstructing societal fabric}

Facadism is often reflected in reshaping the strong elements of a city and giving them new life, maintaining the integrity of the façades and reorganizing them internally, as they carry fundamental cultural, aesthetic, social, and historical value. These values are essential for reshaping the societal fabric [26]. Our experience of the urban environment is a dynamic activity that includes movement and time, and the role of facadism appears in the kinesthetic experience, when the environment is examined as a dynamic and discoverable time sequence. This is accompanied by the recipient's freedom to stop and merge with their surroundings, and this can be achieved through:

-Enhancing the experience of the urban environment as a flexible experience, as it is the art of tension and spaces consisting of a series of closed and open spaces of tension and relaxation. This is in addition to the significant importance of the tension relationship between being here (hereness) and being there (thereness) [33]. Such a relationship requires taking into account the sequential scenes that are achieved in experimentation and exploration with the pleasure of excitement and stimulation by contradictions, and the juxtaposition of place, and a set of hints or references to a different emerging scene [7].

-Content: it is intended by the social environment and the social and human relations it implies, as well as the meanings and values underlying it, and how to enhance it through the physical fabric that contains it [33]. The content is affected by the texture, scale, personality, tones, and colors of natural materials used on the façades and ceilings of buildings, which are often key elements of character, aesthetic quality, and local identity [12].

-Quality of historical façades: the quality of historical façades is one of the main considerations of facadism. The best façades must be preserved, even if their relationship with the interior has decreased over time, and the façade is the main component of the historical building to survive; as such, it will be especially valuable for cultural, aesthetic, or even emotional reasons $[18,26]$.

The literature review reveals that extant research summarizes the important themes and indicators of spatial reconfiguration (Table 1).
Table 1. Teams and indicators of spatial configuration

\begin{tabular}{|c|c|c|}
\hline \multicolumn{2}{|c|}{ Themes } & Indicators \\
\hline $\begin{array}{l}\text { Urban memory } \\
\text { recovery }\end{array}$ & $\begin{array}{l}\text { Investing in } \\
\text { historical/ } \\
\text { heritage values } \\
\text { and symbols }\end{array}$ & $\begin{array}{c}\text { Compatibility between old and } \\
\text { new } \\
\text { Differentiating between old and } \\
\text { new (visual separation) } \\
\text { Highlighting and preserving } \\
\text { historical monuments and } \\
\text { buildings } \\
\text { Promoting contextual value } \\
\text { through historical symbols and } \\
\text { elements } \\
\text { Introducing new structures, } \\
\text { different in their connotations and } \\
\text { characteristics with a common } \\
\text { identity between the past and the } \\
\text { present } \\
\text { Reinforcing connected façades of } \\
\text { buildings and weaving their parts } \\
\text { into a coherent design unit, in } \\
\text { which historical elements and } \\
\text { symbols are gathered } \\
\text { Achieving continuity and } \\
\text { preservation of the original form } \\
\text { Emphasizing the general } \\
\text { functional value within an urban } \\
\text { context }\end{array}$ \\
\hline $\begin{array}{c}\text { Enhance a } \\
\text { place's } \\
\text { personality and } \\
\text { identity }\end{array}$ & $\begin{array}{c}\text { Enhancing the } \\
\text { urban/spatial } \\
\text { experience }\end{array}$ & $\begin{array}{l}\text { Repeating urban style and } \\
\text { preservation of architectural unity } \\
\text { Ensuring rhythm and sequential } \\
\text { vision of the urban scene } \\
\text { Merging scenes with each other } \\
\text { to reach an ideal balance and } \\
\text { achieve the element of surprise } \\
\text { Distinguishing between old and } \\
\text { new, and harmony with the } \\
\text { historical personality }\end{array}$ \\
\hline $\begin{array}{l}\text { Reshape the } \\
\text { societal fabric }\end{array}$ & $\begin{array}{l}\text { Enhancing the } \\
\text { urban/spatial } \\
\text { experience } \\
\text { Physical-social } \\
\text { content } \\
\text { The quality of } \\
\text { historical } \\
\text { facades }\end{array}$ & $\begin{array}{l}\text { Continuity of the urban scene } \\
\text { Spatial juxtaposition (dividers, } \\
\text { direct and emerging views) } \\
\text { Color, texture, scale, personality, } \\
\text { and uniqueness } \\
\text { Promoting functional traditions } \\
\text { (inside) and their relationship to } \\
\text { the historical façade } \\
\text { Preserving the best historical } \\
\text { façades }\end{array}$ \\
\hline
\end{tabular}

\section{THE PRACTICAL STUDY}

This section aims to verify the objective of the research about the possibility of utilizing facadism and its role in the local spatial reconfiguration.

\subsection{Research methodology}

The research relies on the qualitative scale from the questionnaire in extracting the most important types of facadism that achieve spatial reconfiguration according to the opinion of experts and specialists in urban conservation and development, thus, verifying the possibility of applying the facadism approach locally. 


\subsection{The research sample}

The research was based on historical studies and field surveys depending on Al-Waili, which is the most recent field survey documented by the Baghdad Municipality within the Baghdad Historic Center development project. In addition, field surveys conducted by the researchers and field visits to the site that document the problems that took place from September to December 2019 were also used. Three visits took place, with the last visit occurring in December 2020, which included documenting cases with pictures and analysis within the indicators of the theoretical framework and approved studies.

An intentional sample was selected, represented by an elected part of Al-Rasheed Street within the historical center of Baghdad. The spatial boundaries of the study area were identified from the beginning of Al-Rasheed Street (Bab AlMoadham), formerly the northern gate of Baghdad, and represented by the Ministry of Defense at present to the Shuhadaa Bridge, which reflects the problems of the entire street. These problems were taken into account when selecting the site for the practical study: the spatial reconfiguration of this important and vital part of the historic center of Baghdad. The following were key reasons:

The region includes many important urban and architectural features.

Al-Rasheed Street represents an important historical, civilizational, and architectural identity for the city of Baghdad.

The region contains many diverse urban activities that could be the cause of the spatial reconfiguration of the street in particular, and the historical center in general. Despite the continuous and various transgressions on the important street, it is one of the most vital areas in the city of Baghdad.

\subsection{Analytic aspects}

The first aspect is to identify and code the main and minor items for ease of dealing with them in the charts, and for application of the items of the theoretical framework of the research in a manner that defines a general framework according to which the data are analyzed by organizing the questionnaire form (Appendix 1). Then, the relationship between the research variables can be determined.

The second aspect is to conduct a questionnaire for the selected sample, where the form was distributed to a group of architectural and urban design experts and specialists in preservation from various Iraqi architectural schools, as well as specialists in implementation from the Baghdad Municipality and its preservation departments. The number of forms was 60, which included all specialists in the concerned departments. A total of 48 forms were approved and 12 were excluded for lack of completeness.

\subsection{Data processing}

For the validation of the questionnaire and the analysis purpose, a one-way analysis (ANOVA) was used to measure the significance of three-dimensional variables. The results were significant at $\mathrm{p}<0.05$ [34]. And for comparison between variables with different numbers of indicators, Eq. (1) was adopted [34].

$$
\| X i=\frac{x i}{\sum x \mathrm{i}} \times 100 \%
$$

\subsection{Brief history}

In this part, the research presents a description of the chosen study area (noting that the description is attached to the questionnaire form).

The historical area of Al-Rasheed Street is an important part of Baghdad's historical center, as the beginnings of the street date back at least to 1915 , with some studies indicating Babylonian origins $[1,2,35,36]$. It is the first street that was constructed in the historical fabric of the city (Figure 1). The buildings around it were designed in distinctive architectural styles within their historical context (Figure 2), to form an important cultural heritage in Baghdad. The region witnessed a comprehensive deterioration as a result of preservation decisions on the one hand and deliberate and unintentional neglect on the other hand. This affected most of the buildings and led to the deterioration of the urban scene and the spatial formation in general [37].

Several ideas have been proposed to achieve the historical center of Baghdad in developing the old city center and its neighborhoods, so that the heart of Baghdad can return to a distinct and protected heritage center. This could be carried out through a vision based on the three dimensions that make up the urban environment (place - function - time), and dependence on the complementarity between them, where the morphological (spatial), functional, and historical influences, with all their interactions and interconnected elements, constitute the forces affecting the region and its development, by adopting the following three dimensions [1]:

1. Spatial reconfiguration: removing distortions and abuses that offend the urban character, strengthening restoration and preservation of buildings overlooking the street, completing the urban body of the street wall, enhancing the architectural character, legalizing traffic, and providing the necessary services and facilities for pedestrians.

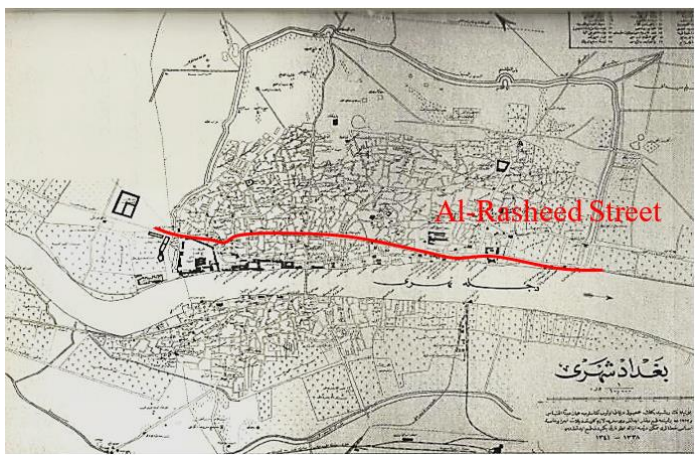

Figure 1. A map of Baghdad in 1919 CE, showing the location of Al-Rasheed Street [37]

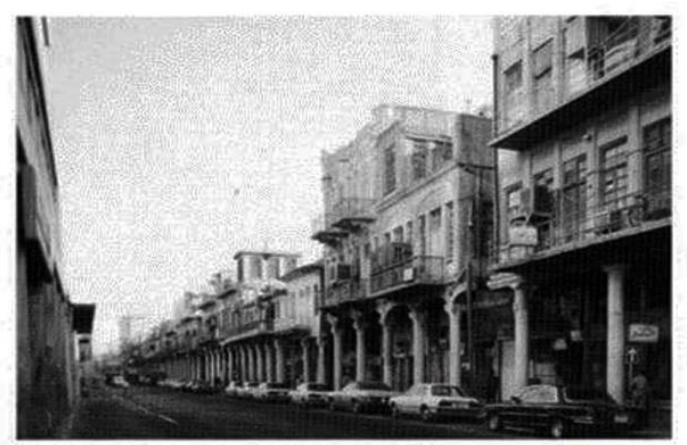

Figure 2. Al-Rasheed Street scene in 1945 [2] 


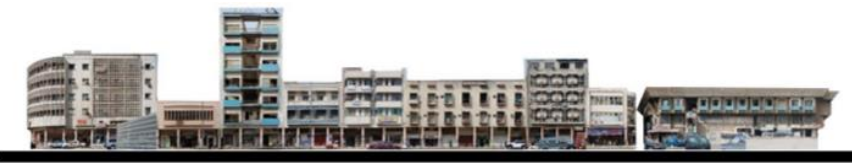

Figure 3. The current state of the façade of the Rasheed Street wall overlooking the south in Bab Al-Sharqi [1]

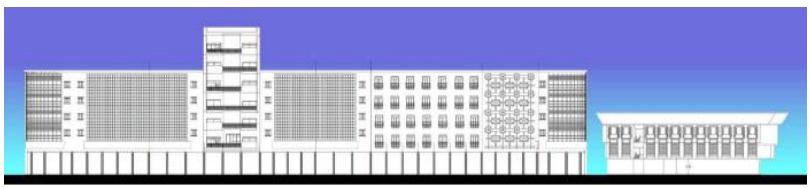

Figure 4. The proposal for the south in Bab Al-Sharqi, standardizing building heights for a consistent street wall [1]

2. Restore functional balance: promote retail and service trade, develop the street as a transit corridor (mall), intensify urban development at the southern and northern outskirts of the street, and exploit the street's dynamic axes to stimulate the region's economies.

3. Restore the urban memory: enhancing the historical character of the street in all the items of development, highlighting the historical architectural features overlooking the street, reviving and embodying heritage symbols related to the history and events of the street, and celebrating the history of the street through artistic embodiment and periodic festivals.

From this, we see that the Baghdad Municipality's proposal to develop the street implicitly includes the facadism approach without a clear definition of the patterns that can be adopted or their details, as shown in Figures 3-4.

\subsection{Suggested interventions in Al-Rasheed street by adopting facadism}

The field survey of Al-Rasheed Street resulted in a set of architectural and urban problems that can be addressed by adopting the facadism approach with its various patterns, thus achieving spatial reconfiguration (Figure 5):

-Random buildings: replacing buildings that were built spontaneously and do not suit the traditional street regulations and determinants with buildings commensurate with the street's heritage and importance (Figure 5-A).

-Unfinished buildings: completing the construction of buildings that have not been completed for decades, or buildings that have collapsed and only the ground floor has been treated, in a manner consistent with the parts of the constructed building in line with the character and heights of the surrounding buildings (Figure 5-B).

-Dilapidated and ramshackle buildings: reconstructing heritage buildings of high value and that are liable to collapse, returning them to the state they were in by using the same construction materials and finishes (Figure 5-C).

-Buildings without columns or corridors: adding the missing architectural elements to suit the prevailing architectural elements in the concerned area and the neighboring buildings (Figure 5-D).

-Distorted buildings: removing distortions and repairing damaged elements of heritage buildings (Figure 5-E).

-Weak buildings: restructuring of the façades devoid of architectural character by adding touches that contain architectural elements that fit with the character of the street (Figure 5-F).

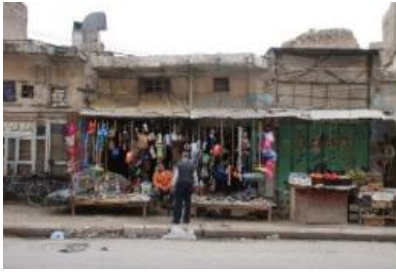

A

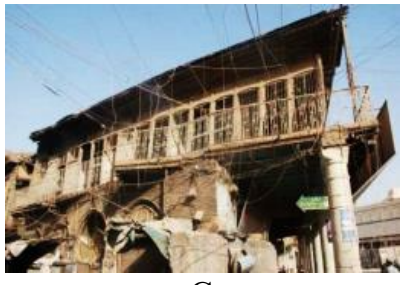

$\mathrm{C}$

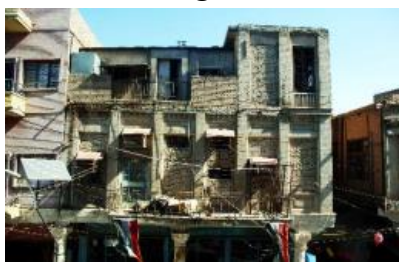

$\mathrm{E}$

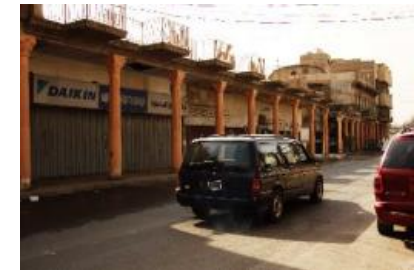

$\mathrm{B}$

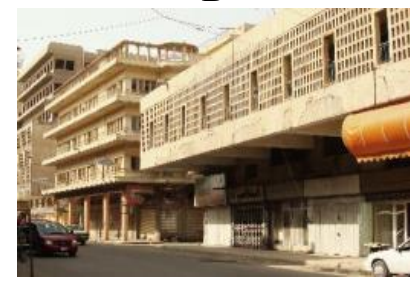

D

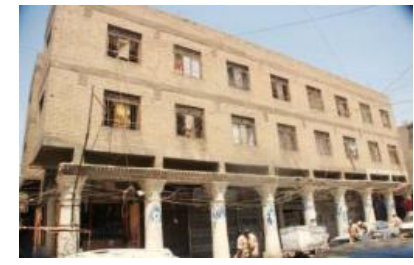

$\mathrm{F}$
Figure 5. Architectural and urban problems captured by the authors

\section{RESULTS AND DISCUSSION}

The final results of the analysis of the items of spatial reconfiguration concerning the patterns of facadism in the questionnaire showed the support of experts and specialists to adopt the facadism approach in spatial reconfiguration. Different proportions were noted according to the pattern, as the effective importance of the facadism patterns for preserving the façade appeared in comparison with the replica facadism style. Further, there is the potential to dismantle and re-create an interface in another place from its original location, as our respondents' observations showed a reservation on the exact construction pattern due to the absence of such practices locally, as well as the lack of sufficient techniques to ensure the reproduction of the shape.

As for dismantling and reconstructing in another place, we witnessed a complete lack of acceptance due to the importance of all the items of the street, as well as the need for its survival and cohesion to preserve the identity and spirit of the place.

The final results related to the secondary items of the façade preservation pattern, as can be seen through the importance of the spatial reconfiguration items. This refers to the quality of the historical façades, the preservation of urban unity, the material-social content, and the investment of historical/heritage values and symbols within the pattern of the wide cavity (Scoop). Using merging symmetric reproduction, the importance of the spatial reconfiguration items for preserving the urban character become clear, enhancing the experience of the urban/spatial environment and the quality of historical façades. Further, investing in historical/heritage values and symbols can be performed, and balance and harmony be distinguished in relation to the pattern of the wide cavity (Scoop): merging-contemporary interpretation, as well as the importance of the spatial reconfiguration items for maintaining urban unity only within the pseudo-tissue pattern (Illusion), in addition to the importance of the items of spatial 
reconfiguration for distinguishing balance and harmony only in relation to the type of separation. The final results associated with the secondary items of the exact reconstruction pattern can also be observed through the importance of the spatial reconfiguration items for preserving the urban character only by demolishing and rebuilding the entire building.

We note that the proportions of the questionnaire for the secondary items of the facadism patterns are achieved through the following.

\subsection{Results related to the secondary items of the façade preservation pattern}

6.1.1 Results associated with the scoop: merging - replication

The results of the analysis showed the importance of the items of spatial reconfiguration for each of the following: quality of the historical façades, the preservation of urban unity, the physical-social content, and the investment of historical/heritage values and symbols, at a rate of verification of $77 \%, 69 \%, 54 \%$, and $48 \%$, respectively. The results of the questionnaire showed a lack of clarity on the effect of facadism on the items of enhancing the experience of the urban/spatial environment, distinguishing balance and harmony, and preserving the urban character, as the verification rate values were low at $35 \%, 23 \%$, and $19 \%$, respectively.

-Results related to the scoop: Merging - contemporary interpretation: The results of the analysis showed the possibility of achieving the items of spatial reconfiguration due to the preservation of the urban character, the enhancement of the experience of the urban/spatial environment, the quality of the historical façades, the investment of historical/heritage values and symbols, and the distinction of balance and harmony. The rate of verification was $58 \%, 50 \%, 50 \%, 48 \%$, and $46 \%$, respectively. This was followed by the items of preserving urban unity by a rate of verification of $42 \%$. In contrast, the effect of the facadism pattern was weak in terms of physical-social content with a rate of verification of $23 \%$.

-Results associated with illusion: The results of the analysis showed the effectiveness of the illusion pattern in the spatial reconfiguration items of preserving urban unity, at a rate of verification of $46 \%$. In contrast, the rate of verification of the items of investing in historical/heritage values and symbols was $38 \%$, followed by the items of distinguishing balance and harmony, enhancing the experience of the urban/spatial environment, and the physical-social content, which all had an equal verification rate of $31 \%$. The items of the quality of historical façades and preserving the urban character came with a low verification rate of $27 \%$ and $23 \%$, respectively.

-Results associated with the sheet/collage pattern: The results of the questionnaire analysis within this pattern showed the weakness of the effectiveness of the spatial reconfiguration items of each of the following: preservation of urban unity, the physical-social content, the investment of historical/heritage values and symbols, the distinction of balance and harmony, and the enhancement of the urban/spatial environment experience. The rates of verification were $38 \%, 38 \%, 37 \%$, $35 \%$, and $31 \%$, respectively. The items of preserving the urban character and the quality of the historical façades also appeared with low verification rates of $23 \%$ and $19 \%$, respectively.

-Results related to the separation pattern: The results of the analysis showed the emergence of the importance of the spatial reconfiguration items of distinguishing balance and harmony, with a rate of verification of $54 \%$. In contrast, the rate of verification for items of preserving the urban character, physical-social content, and enhancing the experience of the urban/spatial environment were $38 \%, 38 \%$, and $35 \%$, respectively. Investing in historical/heritage values and symbols, the quality of historical façades, and preserving urban unity had low verification rates of $22 \%, 19 \%$, and $15 \%$, respectively (see Figure 6).

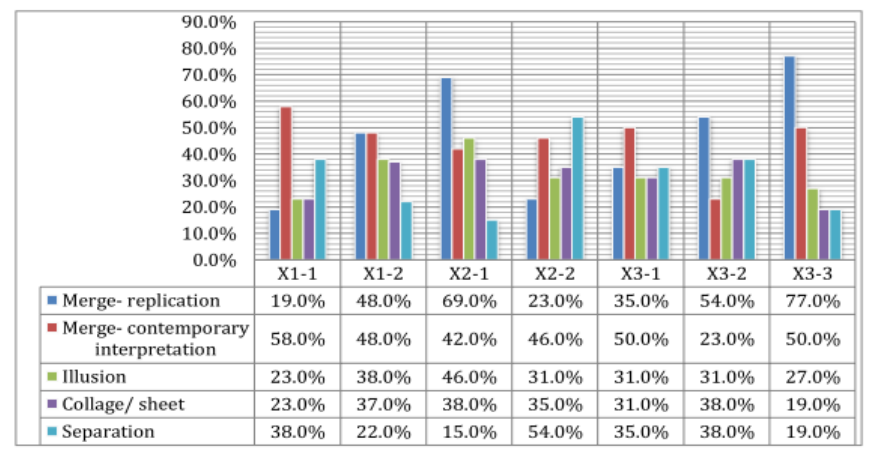

Figure 6. Ratios for verification for the items of spatial reconfiguration according to the facadism patterns related to preserving the façade

6.1.2 Results related to the secondary items of the replica reconstructed pattern

-Results related to the pattern of demolition and rebuilding of the entire building: the results of the questionnaire analysis showed that the experts did not support this pattern in achieving the items of spatial reconfiguration, with the importance of the spatial reconfiguration items related to preserving the urban character only with a rate of verification of $46 \%$. In contrast, the items of the quality of the historical façades and the investment of historical/heritage values and symbols came with a rate of verification of $42 \%$ and $31 \%$, respectively. The items of preserving urban unity, enhancing the experience of the urban/spatial environment, and the physical-social content appeared with an equally lowverification rate of $23 \%$. The item of distinguishing balance and harmony had a verification rate of $19 \%$.

-Results related to the original façade demolition pattern: the results of the analysis of the questionnaire within this pattern also showed the weakness of the effectiveness of the spatial reconfiguration items related to the following: preserving the urban character, investing in historical/heritage values and symbols, distinguishing balance and harmony, enhancing the experience of the urban/spatial environment, and the quality of historical interfaces. All these had an equal verification rate of $27 \%$. The items of preserving urban unity and the physical-social content also achieved a low-equal percentage of verification of $15 \%$ (see Figure 7 ).

6.1.3 Results related to the pattern of dismantling and reconstructing a façade somewhere other than its original location

The results of the questionnaire analysis showed the ineffectiveness of this pattern in achieving the spatial reconfiguration items of physical-social content, which achieved a percentage of $31 \%$. Further, the items of distinguishing balance and harmony, enhancing the experience of the urban/spatial environment, investing in historical/heritage values and symbols, preserving the urban 
character, the quality of historical façades, and preserving urban unity achieved the following rates of verification: $23 \%$, $23 \%, 21 \%, 19 \%, 19 \%$, and $15 \%$, respectively (see Figure 8 ).

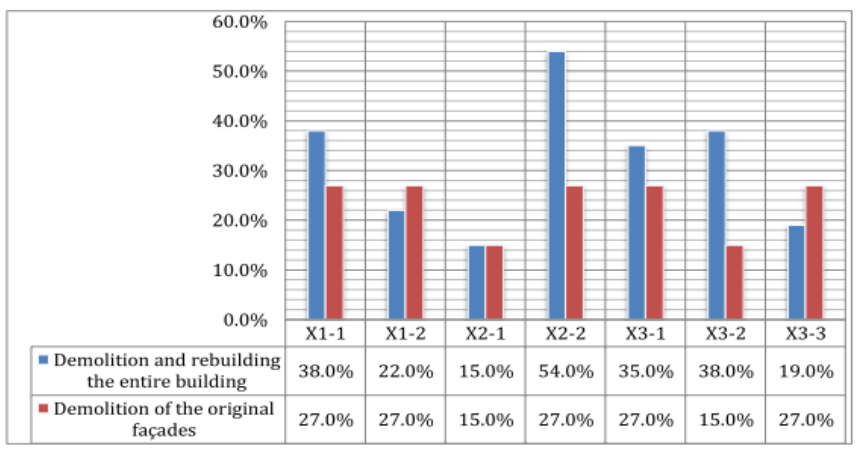

Figure 7. Rates of verification of the items of spatial reconfiguration according to the patterns of the facadism of the exact reconstruction

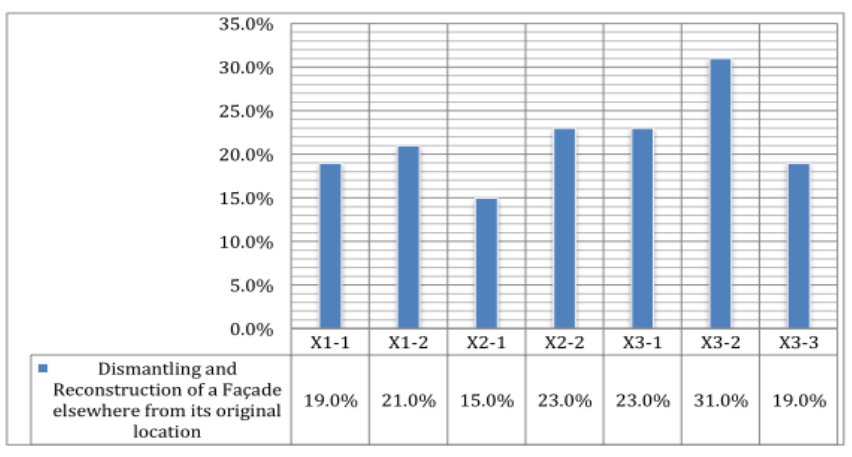

Figure 8. Rates of verification of the items of spatial reconfiguration according to the pattern of dismantling and reconstructing a façade somewhere other than its original location

\section{CONCLUSIONS}

Despite negative views on facadism, several positive aspects of the practice have been expressed over time that have framed it as a fairly correct approach in architecture and urban renewal. The main perceived positive points about facadism include the ability to create a new construction indoors while preserving the façade, which is sometimes considered the most important part of the building. This means that the historic character can be retained through the façade while the remainder of the building is modernized to meet the technical and functional needs necessary for the new use of the building. Perceptions regarding the quality of construction in a historic structure are that it is better than in new constructions, as it is believed that historical structures are usually built in a better and more aesthetically pleasing manner.

The building will be able to connect externally to the neighboring and surrounding context, by preserving the façade of a historic structure. Facadism meets today's needs by providing a usable modern building while preserving the traditional or historic streetscape appearance.

Through the questionnaire, the local experts were asked about the possibility of adopting facadism in the spatial reconfiguration of the historic Al-Rasheed Street in Baghdad. Their results showed clear acceptance and support for the adoption of the preservation pattern, although there was clear reservation in the results regarding the pattern of exact demolition and construction, and the opinion that there is no need to dismantle any building completely and move it to another place.

\section{REFERENCES}

[1] Al Waily, T. (2017). 21st Century Baghdad / Historic City. (Adeeb House, Amman, Jordan). https://www.academia.edu/38629179/Baghdad_21st_Re vival_of_Historical_City.

[2] Stefano, B. (2000). Urban Form in the Arab World - Past and Present (Zurich: https://www.archnet.org/publications/10765.

[3] Wood, K.S. (2012). Architecture of Compromise: A History and Analysis of Facadism in Washington, D.C., Master Dissertation, Graduate School of Architecture, Planning and Preservation, Columbia University. file://C:/Users/Meichuang/Downloads/WOOD_THESI S\%20(3).pdf.

[4] Korumaz, M., Imamoglu, V. (2019). Facadism. Journal of Social and Humanities Sciences Research, 6(43): 3206-3216. http://dx.doi.org/10.26450/jshsr.1528

[5] Kyriazi, E. (2019). Facadism, building renovation and the boundaries of authenticity. Aesthetic Investigations, 2(2): 184-195. https://doi.org/10.5281/zenodo.4073206

[6] Stevens, D.A. (2008). Changing the Perspective of Facadism within San Francisco, Ph.D. dissertation, School of Architecture, University of Hawai'i. https://scholarspace.manoa.hawaii.edu/bitstream/10125/ 45799/1/Stevens_Deirdre\%20Ann_May\%202008.pdf.

[7] Carmona, M., Heath, T., Oc, T., Tiesdell, S. (2003). Public Places - Urban Space: The Dimensions of Urban Space Design. Architectural Press, London.

[8] Spanu, S. (2020). Architecture and the heterotopic concept. Heterotopia and Heritage Preservation, pp. 239386. https://doi.org/10.1007/978-3-030-18259-5_4

[9] Hakim, B.S. (2008). Mediterranean urban and building codes: origins, content, impact, and lessons. Urban Design International, 13(1): 21-40. https://doi.org/10.1057/udi.2008.4

[10] Bosworth, C.A. (2007). Historic Cities of the Islamic World. (Koninklijke Brill NV, Netherlands). Historic Cities of the Islamic World. http://nessia.org/files/original/7fb5287183e94fb6ea34e8 c74d7f9de9.pdf.

[11] Lodge, B. (2020). Facadisme - Conservation, Compromise or Contradiction, MArch Dissertation, Sheffield School of Architecture, University of Sheffield.

[12] Murtagh, W.J. (2006). Keeping Time: The History and Theory of Preservation in America, Third Edition, (John Wiley \& Sons, Inc.).

[13] Walsh, N.P. (2019). Facadism: When Walls Talk, and Lie, Arch Daily's. https://www.archdaily.com/.

[14] Richards, J. (2015). Facadism, (Routledge, 1994). https://www.routledge.com/Facadism/Richards/p/book/ 9780415756020.

[15] du Cros, H., McKercher, B. (2015). Cultural Tourism, (Routledge, Second Edition).

[16] Finkelstein, E. (2014). Extreme Adaptive Reuse: The Analytics of Deconstruction and the Upcycling of Building Materials, Master Dissertation, Dalhousie University, Halifax, Nova Scotia. https://www.bac- 
lac.gc.ca/eng/services/theses/Pages/item.aspx?idNumbe $\mathrm{r}=1032996220$.

[17] Rohiman, W. (2017). Spatial Overlay: Valuing the existing through Juxtaposition, Master Dissertation, School of Architecture, Faculty of Engineering and Built Environment (EBE), University of Cape Town (UCT).

[18] Bargery, R. (2019). The Ethics of Facadism: Pragmatism versus Idealism, The Building Conservation Directory. https://www.buildingconservation.com.

[19] The Gentle Author. (2019). The Creeping Plague of Ghastly Facadism. Spital fields Life Books.

[20] Ellin, N. (2019). Postmodern Urbanism. Princeton Architectural Press, Revised Edition.

[21] Frecker, J. (2019). Facadism: Pandemic of urban life or hard pill to swallow? https://www.urban.com.au/news/facadism-pandemic-ofurban-life-or-hard-pill-to-swallow.

[22] Highfield, D. (2003). The Construction of New Buildings Behind Historic Facades. Taylor \& Francis, London. https://doi.org/10.4324/NOE0419151807

[23] Henry, T.J. (2013). Facadism as an approach to redevelopment and conservation of world heritage. Cultural Heritage and Sustainability, Vol. 5. Technische Universiteit https://pure.tue.nl/ws/files/4418158/765936.pdf.

[24] Al-Hinkawi, W.S., Al-Sadawi, B. (2019). Restoring the local heritage and its role in sustainable spatial development the great market in Al-Najaf-A case study. Engineering and Technology Journal, 37(1 Part C): 4958. https://doi.org/10.30684/etj.37.1C.8

[25] Semes, S.W. (2018). The past and future city: how historic preservation is reviving America's communities. Journal of Urbanism, 11(4): 505-508. https://doi.org/10.1080/17549175.2018.1473948

[26] Al-Saadawi, B.A., Al-Hinkawi, W.S. (2020). Role of urban malleability's mechanisms on sustaining cities. In IOP Conference Series: Materials Science and Engineering, 745: 012165. https://doi.org/10.1088/1757899X/745/1/012165

[27] Hurley, A. (2012). Beyond Preservation, Using Public History to Revitalize Inner Cities. Temple University Press.
[28] Robertson, J. (2020). Old meets new: Historic buildings in a modern city. https://www.designbuild Network.com. Last Updated January 30th.

[29] Almukhtar, A. (2020). Place-identity in historic cities; The case of post-war urban reconstruction in Erbil, Iraq. Urban Heritage Along the Silk Roads, 121-136. https://doi.org/10.1007/978-3-030-22762-3_9

[30] Stavreva, B. (2017). New vs Old: New Architecture of Purpose in Old Settings. Master Thesis, Faculty of the Virginia Polytechnic Institute and State University.

[31] Smith, P.F. (1980). Urban Aesthetics. Studio Vista, London, 74-86.

[32] Grimmer, A.E., Weeks, K.D. (2010). New Exterior Additions to Historic Buildings: Preservation Concerns. National Park Service, U.S. Department of Interior. https://www.nps.gov/tPS/how-to-preserve/briefs/14exterior-additions.htm.

[33] Cullen, G. (1961). Townscape, Architectural Press, London.

[34] Taherdoost, H. (2020). Different types of data analysis; data analysis methods and techniques in research projects. International Journal of Academic Research in Management (IJARM), 9(1): 1-9.

[35] Abdel Hamid, H.B. (2002). Al Rasheed Street (General Cultural Affairs House).

[36] Hussein, S.A., Al-Taee, M.D. (2021). The management of heritage buildings in historical urban areas according to cost-benefit methods. IOP Conference Series: Earth and Environmental Science, 779: 012045. https://doi.org/10.1088/1755-1315/779/1/012045

[37] Al-Hinkawi, W.Sh., Zedan Sh. K. (2021). Branding for cities: The case study of Baghdad. In IOP Conference Series: Earth and Environmental Science, 779: 012037. https://doi.org/10.1088/1755-1315/779/1/012037

\section{APPENDIX}

Questionnaire form for measuring the verification of spatial reconfiguration vocabulary through types of facadism.

Identity of the respondent:

\begin{tabular}{|l|l|l|l|l|}
\hline Specialization of the Respondent & Architect & Planner & other & \\
\hline Profession & academic & Professional - executive & Years of Experience & Notes: \\
\hline
\end{tabular}

\begin{tabular}{|c|c|c|c|c|c|c|c|c|c|c|c|}
\hline \multirow{3}{*}{\multicolumn{3}{|c|}{ Spatial Reconfiguration }} & \multicolumn{5}{|c|}{ The Preservation of the Façade } & \multicolumn{2}{|c|}{$\begin{array}{c}\text { Faithful } \\
\text { Reconstruction }\end{array}$} & \multirow{3}{*}{\begin{tabular}{|c|} 
Dismantling and \\
reconstruction \\
of a façade \\
elsewhere from \\
its original \\
location
\end{tabular}} & \multirow{3}{*}{ Notes } \\
\hline & & & \multicolumn{2}{|c|}{ Scoop } & \multirow{2}{*}{ Illusion } & \multirow{2}{*}{ Sheet / } & \multirow{2}{*}{ Separation } & \multirow{2}{*}{$\begin{array}{c}\text { Demolition } \\
\text { and } \\
\text { rebuilding } \\
\text { the entire } \\
\text { building } \\
\end{array}$} & \multirow{2}{*}{\begin{tabular}{|c|} 
Demolition \\
of the \\
original \\
façades
\end{tabular}} & & \\
\hline & & & replication & interpretation & & & & & & & \\
\hline \multirow{4}{*}{$\begin{array}{l}\text { Urban } \\
\text { memory } \\
\text { recovery }\end{array}$} & \multirow{2}{*}{$\begin{array}{l}\text { Maintaining an } \\
\text { urban character }\end{array}$} & $\begin{array}{c}\text { Compatibility } \\
\text { between old and } \\
\text { new }\end{array}$ & & & & & & & & & \\
\hline & & $\begin{array}{c}\text { Differentiation } \\
\text { between old and } \\
\text { new (visual } \\
\text { separation) } \\
\end{array}$ & & & & & & & & & \\
\hline & \multirow[t]{2}{*}{$\begin{array}{c}\text { Investing in } \\
\text { historical/heritage } \\
\text { values and symbols }\end{array}$} & $\begin{array}{l}\text { Highlighting and } \\
\text { preserving } \\
\text { historical } \\
\text { monuments and } \\
\text { buildings }\end{array}$ & & & & & & & & & \\
\hline & & $\begin{array}{l}\text { Promote contextual } \\
\text { value through }\end{array}$ & & & & & & & & & \\
\hline
\end{tabular}




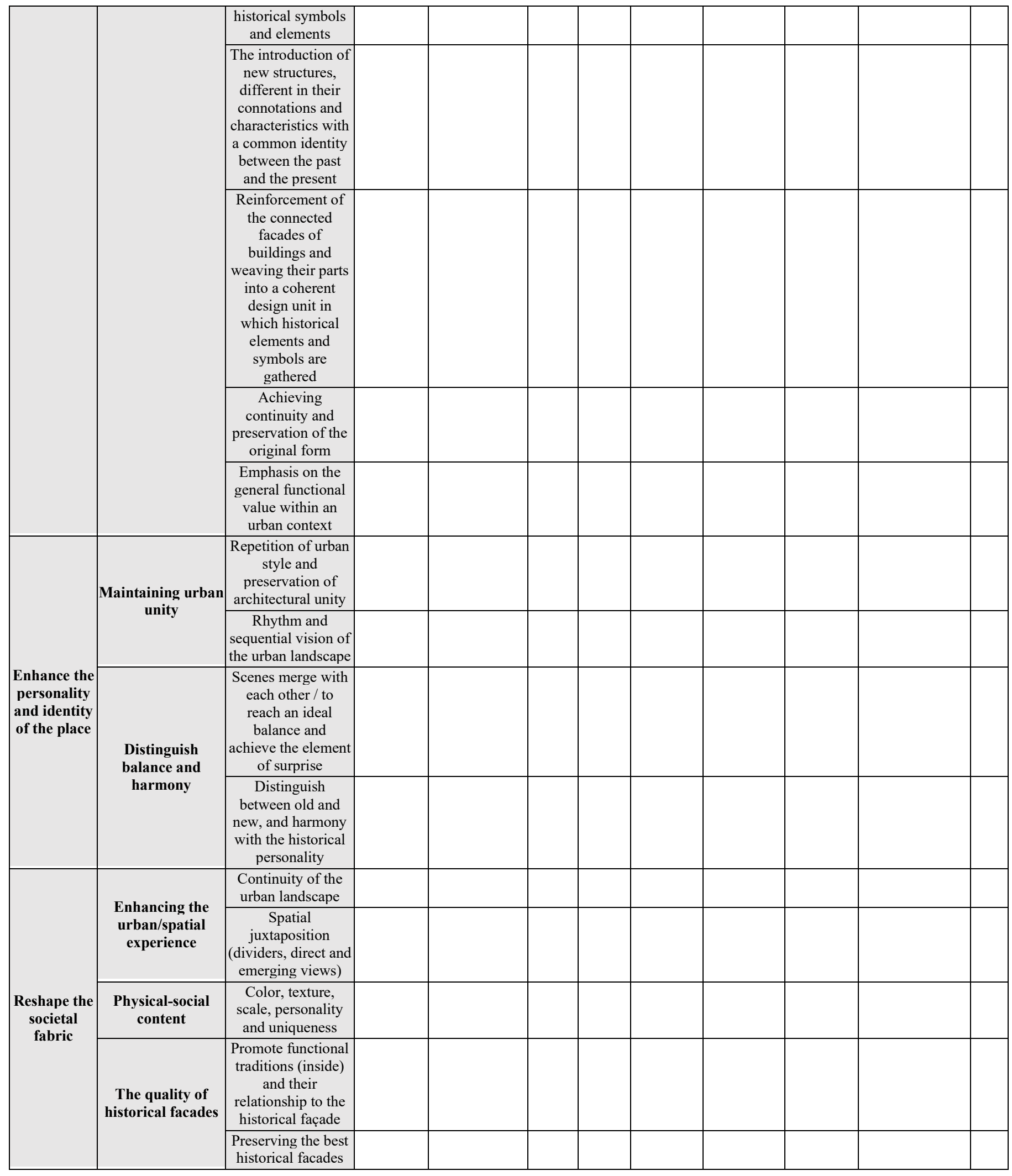

